\title{
IOSPRYAL
}

\section{REVIEW I Kick It: A Social History of the Drum Kit}

\author{
Matt Brennan \\ New York, NY: Oxford University Press, 2020 \\ ISBN 9780190683870 (PB)
}

\section{Bill Bruford \\ Unaffiliated scholar \\ academic@billbruford.com}

The story of the journey of the drum kit, from marginalised obscurity in the bowels of vaudeville to its centralised position in almost all forms of popular music a century later, has much to tell us about those who invented it, the practitioners who practice upon it, the composers who compose for it, the listeners who listen or dance to it, and the expectations and desires of the greater society in which it has its place. The drum kit today is ubiquitous throughout both audio-visual media and live performance. The contemporary rock group King Crimson even has three drumkits at the front of the stage: all other performers to the rear.

Matt Brennan is a researcher and experienced drummer with boundless enthusiasm for his topic. On the assumption that we can all now agree that drums are real instruments, that drummers are real musicians, and drumming is a real art form, he feels the subject deserves a history that accords it an appropriate level of dignity and respect, a history that "interrogates the social construction of musical value from the bottom up" (5). Placing the topic "at the centre of cultural history has the potential to illuminate a broad range of wider issues relevant not just to drummers, but to a much wider audience" (7). Key questions ask how musical history might have been different had the drum kit not been invented, and what such a history might tell us about how the meanings of everyday concepts such as 'musician', 'technique', 'creativity', and 'authorship' have changed over time to the present.

The book's chapters engage with six negative drummer stereotypes: drummers are dumb, noisy, illiterate, uncreative, broke, and replaceable, and seek to resituate them as the positives that they have in many cases become: drummers are clever, musical, studious, creative, working, and indispensable. Brennan's well-supported thesis is that these old stereotypes, originally applied to drummers, are enlisted to 
dismiss popular music as a whole. When we reclassify the sounds emanating from these "instruments of a lower order" (66) as music rather than noise, he suggests, it "undermines traditional pitch-based musical hierarchies that Western culture relies upon for its power" (316). The development of the drum kit and its deployment in ragtime was seen by a cultural elite as nothing short of a direct challenge to cultural imperialism. Provocation, then, is immediately at hand.

Topics cover the origin of the early trap drummer's kit in the interaction and remixing of numerous immigrant cultures in a new country in the $19^{\text {th }}$ century; the centre-stage role of the new instrument in the development of music styles such as ragtime; the move from the multi-adorned 'trap' kit to the sleek, modern kit as espoused in the 1930s, most famously by Gene Krupa; and the subsequent fierce competition of drum manufacturers to create and then dominate the new market in pre-bundled drum 'outfits'. Three musical worlds provided the foundation for the modern drum kit: military music, African-American music, and theatre music. Detailed research leads the author to conclude that there were seldom single inventors of the instrument's various components, that there are multiple origin narratives, and that drummers, being inveterate tinkerers, were probably tinkering at roughly the same time across vast distances in ignorance of the parallel activities of their colleagues and competitors.

Digressions through American bebop or British beat music avoid descent into a mere list of names and provide context for weightier issues such drumming as a form or authorship, the implications of copyright, or the impact of the globalisation of drum kit production. The distinction between high and low art, or the rise of the back beat, for example, offer a necessary and sufficient framing to explain why drummers did the things they did and why instrument manufacturers developed instruments to accommodate them.

Profound concerns within the drum community, such as the contemporary existential threat to instrument and performer alike from digital drum kit replacement technologies, or the creative agency of practitioners and their "uneasy status somewhere between support personnel and (...) fully fledged 'artist'"(205), are skilfully interwoven with Brennan's sharp observations of life as it is lived behind the kit. We duck down into delightful alleyways for minutiae such as the origin of the phrase to 'drum up business', the invention of the (floor-level) 'sock' cymbals, the effect of the 'talkies' on employment (18,000 professional drummers lost their jobs in cinema in less than two years); and the origin of the famous 'drop T' Beatles logo on the group's front bass drum head.

The book might have benefitted from a clearer framing of the author's interpretation of what exactly constitutes a drum kit and the practice of a drummer. Both terms, one might have thought, were generally agreed: the former being an assemblage of electro-acoustic percussion instruments played generally with all four limbs, and the latter a specialist who performs music upon it. However, with the democratisation of music invention in the post-digital ecology, the need for experts and specialists wanes. If Brennan's redefinition of the occupation is to include software coders, sound designers, contemporary beat-makers and producers such as J. Dilla, none of a contemporary drummer's four limbs need ever touch the assemblage of percussion instruments that the author has described in such an interesting and lively manner over three-quarters of the book. The question "can a viola player be a viola player if she never touches a viola?" is of interest to more than viola players. With the computer as part (or all) of the drum kit, typically the case within contemporary recording practice, we have all already begun to march to the beat of a very different drummer. 
Viewed as "a technology that provide(s) structure for human activity" (316), the change that technology has wrought has had profound implications for practitioners. Drummers tend to play patterns and computers are particularly good at patterns. It is thus no surprise that one early piece of electronic equipment designed to interface with musicians was the drum machine rather than, for example, the saxophone machine. Sonically, an acoustic drum kit is a minefield of overtones and sympathetic vibrations - complex, and thus expensive, to capture. Given the ready availability of downloadable drum tracks and samples, many young producers and recordists have never attempted to capture one. Nine Inch Nails' producer Trent Reznor's idea of a drum is "a button on a machine" (306).

The vast majority of contemporary recorded popular music, arguably, is made without a rhythm specialist present, which is precisely why, some suggest, it sounds the way it does. But the direction of travel is one way only: away from the unsustainable delights of carbon-heavy, expensive, uncontrollable live performance, subject on occasion to severe disruption, towards the less expensive, more controllable, virtual, online paradigm of music generation. Indeed the bleakest prognosis posits the disappearance of the dedicated single instrumentalist altogether, starting with the bass player and drummer, or at least their eventual relegation to $21^{\text {st }}$ century 'Early Music Consorts' that seek to relive the 'glory days' of the late $20^{\text {th }}$ century.

The strength of this excellent and enjoyable publication emanates Brennan's undoubted passion for the subject: his enthusiasm is contagious. In his view, history is story-telling. To structure a history of anything is a decision-making process: which stories to leave in, which to leave out? He has chosen wisely. At the beginning of this valuable volume, drums stood, in Henry Krehbiel's alarming phrase from 1897, "on the borderline between savage and civilized music" (1897: 68). By the end, the sounds they make have been re-designated as music rather than noise, and accorded an indispensable centrality within contemporary music invention. Now that we are all drummers, specialist purveyors may paradoxically be an endangered species facing a grim redundancy.

A social history it may be, but along the way myriad sparkling tributaries lead off into cultural, economic, psychological and entrepreneurial pastures, the better to realise more fully Brennan's mission "to make sense of the history of the status of the drummer as a musician, the drum kit as an instrument, and drumming as a practice, and how they have interacted with the wider world" (8). The pace of scholarship on the instrumentalist and her instrument has quickened. This volume succeeds in reminding us of the virtue of a 'bottom up', 'instrument-led' approach in bringing together several developing threads in the discourse into the most comprehensive book on the topic your reviewer knows.

\section{References}

Krehbiel, H. 1897. How to Listen to Music: Hints and Suggestions to Untaught Lovers of the Art. New York: Charles Scribner's Sons. http://www.gutenberg.org/files/17474/17474-h/17474-h.htm. 